\title{
Małgorzata Potoczna*
}

\section{PRACA W DOŚWIADCZENIU BIOGRAFICZNYM TRZECH GENERACJI KOBIET Z LÓDZKICH ENKLAW BIEDY}

\begin{abstract}
Abstrakt. Łódź nazywana jest miastem pracujących kobiet. Przez ponad dwieście lat rozwój miasta, losy życiowe i sytuacja zawodowa jej mieszkańców były związane z funkcjonowaniem zakładów przemysłu tekstylnego, włókienniczego, odzieżowego, które oferowały zatrudnienie przede wszystkim kobietom ${ }^{1}$. Artykuł traktuje o znaczeniu pracy zarobkowej w generowaniu sytuacji życiowej trzech generacji łódzkich kobiet. Wskazuje znaczącą rolę, jaką w przełamywaniu lub ześlizgiwaniu się w biedę mieszkanek przemysłowej Łodzi odegrały - determinowane przez wydarzenia historyczne (II wojna światowa), a przede wszystkim procesy społeczno-ekonomiczne (dekoniunktura gospodarcza lat międzywojennych, powojenna transformacja ustrojowa i transformacja systemowa lat 90.) - zmiany zachodzące na łódzkim rynku pracy. W doświadczeniu starszej generacji mieszkanek Łodzi powojenna transformacja ustrojowa, w głównej mierze procesy intensywnej industrializacji i nacjonalizacji przemysłu, gwarantując szeroki dostęp do pracy zawodowej, otworzyły wykorzystaną przez wiele z nich szansę wyjścia z biedy, doświadczanej w okresie międzywojennym, w rodzinach pochodzenia. Dla pokolenia ich córek, które wkroczyły w życie dorosłe na przełomie lat 70. i 80., podejmując podobnie jak matki bez większych problemów pracę zawodową, stanowi ona szansę na utrzymanie względnie stabilnej sytuacji materialnej w kolejnym pokoleniu. Sytuację życiową kobiet średniej generacji oraz kolejnej, młodszej, w znaczący sposób zmienia zapoczątkowany w latach 90. proces restrukturyzacji łódzkiego przemysłu włókienniczego. W efekcie tych zmian kobiety średniej i młodszej generacji tracą możliwość utrzymania pracy, młodszej - podjęcia pracy zawodowej w ogóle, obie generacje zasilają w ten sposób kategorię osób zbędnych na rynku pracy.
\end{abstract}

Słowa kluczowe: praca, bieda kobiet, transformacja systemowa, wykluczenie społeczne.

${ }^{*}$ Dr, Katedra Socjologii Stosowanej i Pracy Socjalnej, Instytut Socjologii, Wydział Ekonomiczno-Socjologiczny, Uniwersytet Łódzki, ul. Rewolucji 1905 r. nr 41/43, 90-214 Łódź; e-mail: matmalmar@poczta.onet.pl.

${ }^{1}$ Pierwsze zakłady włókiennicze w Łodzi powstały w 1823 r., w 1911 fabryki zatrudniały 86442 tys. robotników. Liczba zatrudnionych dynamicznie rosła i w 1923 wynosiła 115 tys. W 1934 załogę niektórych zakładów włókienniczych w 70, a nawet 90\% stanowiły kobiety (J a ż d ż y ń s k a 1958). Na przełomie XIX i XX w. w Łodzi lokowała się połowa wszystkich zakładów tekstylnych i 54\% globalnej produkcji włókienniczej ówczesnej Polski. 


\section{Wprowadzenie}

W perspektywie biografii jednostki praca zawodowa stanowi jedną z podstawowych form aktywności, które strukturalizują przebieg życia i wyznaczają formatywny zakres doświadczeń biograficznych. Posiadanie pracy gwarantuje uczestnictwo w świecie społecznej konsumpcji. Umożliwia jednostce uzyskanie praw socjalnych, wyznacza dostęp do ważnych instytucji społecznych. Dzięki pracy jednostka zyskuje określoną pozycję i tożsamość społeczną, realizuje swoje zainteresowania i aspiracje (P o le s z c zuk 1991: 108).

Praca stanowiąc także jeden z najważniejszych elementów koncepcji ładu społeczno-ekonomicznego w perspektywie biografii jednostki, „dzieje się” zawsze zgodnie z regułami działania, ustalonymi przez warunki społeczne, ekonomiczne, polityczne, kulturowe. To one, tworząc tzw. warunki brzegowe, stają się dla jednostek elementami obiektywnej przestrzeni społecznej, które w znaczący sposób wyznaczają szanse i ograniczenia realizacji aspiracji biograficznych, nie tylko zawodowych, lecz także edukacyjnych czy rodzinnych.

W II połowie XX w. społeczeństwo polskie dwukrotnie, w latach 1945 i 1989, doświadczało fundamentalnej zmiany warunków, określających możliwości kształtowania przebiegu biografii zawodowej. Pierwsza, powojenna transformacja „od kapitalizmu do socjalizmu”, oparta na strategii industrializacji kraju, wspieranej przez realizację zasady pełnego zatrudnienia gwarantuje jednostce pewność i bezpieczeństwo zatrudnienia, niezależnie od posiadanych, nie zawsze wysokich, kwalifikacji (P ole s z c zuk 1991). Nowe warunki, określające możliwości kształtowania przebiegu indywidualnej biografii zawodowej, przyniósł proces dezindustrializacji i wprowadzenie gospodarki kapitalistycznej w jej formie neoliberalnej w latach 90. Postępujący proces decentralizacji i flexibilizacji miejsca i czasu pracy zarobkowej - wprowadzając elastyczne pod względem czasu i przestrzeni, pluralistyczne formy pracy zarobkowej (m.in. zatrudnienie w niepełnym wymiarze czasu, prace zlecone, praca „na czarno" i w szarej strefie), które wypierają etatowe zatrudnienie na podstawie klasycznego stosunku pracy w pełnym wymiarze czasu pracy oraz zjawisko bezrobocia, które ,staje się normalnym, tymczasowym wydarzeniem standardowej biografii zawodowej" (B e ck 2002: 139) - powoduja, że w konsekwencji stałym elementem przebiegu biografii zawodowej jednostek jest zagrożenie utratą pracy lub wymuszone zmiany pracy, motywowane nie względami materialnymi czy aspiracjami zawodowymi, ale tym, że ,jednostka wchodzi na rynek pracy nie wtedy, gdy chce lub, gdy jest zmuszona do podjęcia pracy dostarczającej jej środków do życia, lecz wówczas, gdy na rynku

${ }^{2}$ Założenia polityki gospodarczej państwa realnego socjalizmu, akcentując opiekuńczą funkcję państwa, zakładały zasadę dostępności znacznej części dóbr i usług „,według potrzeb”, rozbudowę sytemu świadczeń społecznych, utrzymywanie dochodów i cen artykułów (przede wszystkim żywności) oraz usług konsumpcyjnych na niskim, minimalnie zróżnicowanym poziomie. 
pracy istnieją możliwości jej zatrudnienia" (P oles z c zuk 1991: 110). Procesy zmian, które dokonały się na rynku pracy po $1990 \mathrm{r}$. spowodowały, że pracodawcy wyraźnie preferują osoby o wysokich kwalifikacjach zawodowych. Pozycję na rynku pracy i typ kariery zawodowej, mobilność zawodową, brak lub mniejsze zagrożenie bezrobociem, poziom uzyskiwanych dochodów, atrakcyjność zatrudnieniową wyznacza i potwierdza posiadany przez jednostkę indywidualny kapitał kompetencji, kwalifikacji zawodowych i ogólnych. Artykuł prezentuje znacznie pracy w doświadczeniu biograficznych trzech generacji kobiet oraz wskazuje, na jakie szanse i na jakie ograniczenia/bariery napotykały na łódzkim rynku pracy. Tekst powstał na podstawie analizy wywiadów biograficznych typu family life histories, które zostały przeprowadzone w ramach dwóch projektów badawczych, zrealizowanych przez Instytut Socjologii $\mathrm{UŁ}^{3} \mathrm{z}$ kobietami reprezentującymi dwie lub trzy generacje łódzkich rodzin doświadczających biedy. Starsze pokolenie, „babki”, reprezentuja kobiety w wieku 65-85 lat; średnie pokolenie, „matki” (córki starszego i matki młodszego pokolenia), mieszkanki łódzkich enklaw biedy, klientki pomocy społecznej, są w wieku 45-54 lata; młodsze pokolenie, „córki”" (córki średniego, wnuczki starszego pokolenia) to kobiety w wieku 19-25 lat.

\section{Praca jako konstytutywne doświadczenie biograficzne starszej generacji kobiet}

Ciężka, kilkudziesięcioletnia praca zarobkowa jest najbardziej charakterystyczną cechą biografii starszej generacji kobiet. Już w okresie wczesnego dzieciństwa, które przypadło na trudny historycznie okres lat międzywojennych zmuszone były podejmować pracę zarobkową. Wywodzą się z małorolnych rodzin chłopskich, najczęściej wielodzietnych, doświadczających niejednokrotnie skrajnej biedy, w których dzieci od najmłodszych lat angażowane były do pomocy

${ }^{3}$ Były to projekty: Formy ubóstwa i zagrożeń społecznych oraz ich przestrzennego rozmieszczenie w Lodzi (projekt zamawiany PBZ nr 018 08), zrealizowany w latach 1998-1999 oraz Wzmocnić szanse i osłabić transmisję biedy wśród mieszkańców miast województwa łódzkiego -WZLOT, zrealizowany w latach 2008-2010 (grant z PO KL). Wywiady biograficzne przeprowadzono w ramach komponentu projektu pt. Mieszkańcy łódzkich enklaw biedy po 10-ciu latach. Badania zrealizowane w latach 1998-1999 pozwoliły odtworzyć proces tworzenia się izolowanych przestrzennie i społecznie obszarów biedy w Łodzi. Wznowione 10 lat później dostarczyły wiedzy o mechanizmach utrwalania biedy i wykluczenia społecznego w cyklu życia i ujęciu międzypokoleniowym, wśród tych, którzy są potomkami osób doświadczających masowego bezrobocia z lat 90 . Analogicznie, w latach 1989 i 2008, przeprowadzono 90 wywiadów wśród osób wchodzących w skład 40 (1989 r.) i 49 (2008 r.) rodzin. W 2008 wśród badanych znalazło się 30 rodzin należących do próby z roku 1998. Szczegółową charakterystykę badań znajdzie czytelnik w pozycjach książkowych: Golczyńska-Grondas (2004); Jankowski, Warzywoda-Kruszyńska (2010); Potoczna, Warzywoda-Kruszyńska (2009); Warzywoda-Kruszyńska, Jankowski (2013). 
w pracach polowych w gospodarstwie rodziców: Wszyscy robili w polu. Każdy, co mógł to robit, ja jak rodzice poszli na pole, ja też musiałam, chociaż mała dziewczynka byłam $(\mathrm{Q} / 3)^{4}$. Ponieważ niewielkie gospodarstwa rodziców nie zabezpieczały potrzeb rodziny, narratorki starszej generacji zmuszone były przerwać naukę i pójść „,na służbę”, żeby zarabiać na siebie i w ten sposób pomagać utrzymać rodzinę: Ja bytam w domu najstarsza, bardzo ciężko miałam, [...] tylko dwie klasy skończyłam, bo później to musiałam iść do gospodarza pasać krowy, miałam może 10, a może 11 lat, pare grosików dostawatam (B/3). W czasie II wojny światowej część z nich została wywieziona do pracy przymusowej do Niemiec: Miałam 15 lat jak mnie wywieźli do Niemiec. Byłam w Meklemburgu u gospodarza. Rano wstawatam o pierwszej, krowy musiatam doić, 15 krów, to ręce tak mnie bolaty, że w nocy spać nie mogłam, jak wydoiłam krowy - śniadanie, statki [naczynia kuchenne] zmyłam, kuchnie wytarłam $i$ w pole robić. Zima tez ciężka praca była, ja na polu obornik roztrzasałam (B/3). Te, którym udało się uniknąć tego losu, „służyły” w gospodarstwach przejętych przez osiedlających się na ziemiach polskich gospodarzy niemieckich: Trzynaście lat miałam jak u Niemców służyłam, na gospodarstwie pracowałam od czterdziestego do czterdziestego piqtego, dzieci bawitam, krowy pasłam, $i w$ domu robiłam, $i$ w pole się szło. Wszystko tam robitam (I/3). Część z rodzin, uciekając przed biedą doświadczaną na wsi, w poszukiwaniu lepszych warunków do życia w okresie międzywojennym migrowała do Łodzi. Ojcowie bez zawodu i bez wykształcenia podejmowali niskopłatną pracę zarobkową jako robotnicy niewykwalifikowani w zakładach włókienniczych lub dorywczą w branży budowlanej: Mój tatuś, to byt zwykty robotnik, nie miat zawodu, nie umiat czytać ani pisać. Mama to samo. Nie umiała pisać, nie umiała czytać (C/3). W okresie kryzysu ekonomicznego lat 1929-1933 tracili stałą pracę. W okresie letnim szansę zdobycia środków finansowych dawała jedynie praca dorywcza. W okresie zimowym rodziny korzystały ze świadczeń społecznych lub z przysługującego niektórym prawa do zasiłku państwowego w sytuacji bezrobocia: Tata pracowat tylko $w$ sezonie, bo byt stolarz i cieśla, a mama wcale. Pamiętam, jak czekaliśmy w sobote, jak tatuś przyjdzie, to wychodziliśmy przed brame, bo tatuś zawsze nióst taki duży bochenek chleba. Dobry mój tatuś byt, dbat $i$ chciat jak najlepiej [...], ale nie byto tej pracy $(\mathrm{O} / 3)$. Gdy prace tracił ojciec, matki szukały możliwości zarobku: Mamusia jak było ciężko, no to zostawiała nas pięcioro dzieci $w$ domu i szła szukać chleba. A to poszła do Żydów prać, a to sprzqtać i przychodziła wieczorem, a my czekaliśmy po prostu na jedzenie. Jak ta Żydówka jak wiedziała, że matka ma dzieci małe, to dała więcej tego jedzenia. A jak nie, to zaptaciła pieniędzmi, to dopiero żeśmy jadty na drugi dzień. Jak już mama ugotowata raz na dzień, to już nakarmita nas tyle, żebyśmy się najadty. Takie to byto życie nasze. Byto biednie, biednie byto, byto bardzo biednie (D/3).

${ }^{4}$ Wszystkie cytaty wykorzystane w artykule pochodzą z pozycji: P o t o c z n a, W a r z y w o da - Kruszyńska (2009). 
Dlatego narratorki, które spędziły dzieciństwo w Łodzi, zostały obciążone obowiązkami opieki nad młodszym rodzeństwem: To mój czas jak dla dziecka to byt bardzo smutny, bo ja cały dzień zajmowałam się dziećmi, mamusia szła do pracy na cały dzień (W/3). W czasie wojny niektóre pracowały w niemieckich zakładach odzieżowych: Zaczęłam pracować, jak miałam 11 lat $w$ fabryce tu u Wullego, ponieważ mamusia leżała, tatuś byt na wojnie i brat byt na wojnie, siostra moja była jeszcze $w$ domu młodsza, więc ja prawie utrzymywałam ten mój cały dom, pracowałam po 12 godzin, od szóstej do szóstej (O/3).

\section{Praca w socjalistycznym zakładzie pracy jako doświadczenie starszego i średniego pokolenia}

Starsze pokolenie kobiet reprezentuje - opisywany w literaturze przedmiotu, ukształtowany w pierwszych latach po wojnie - model kobiety bohaterki socjalistycznego zakładu przemysłowego. Powojenna, bardzo trudna sytuacja materialna w rodzinach sprawiała, że podjęcie pracy przez narratorki stało się materialną koniecznością. Tym samym kontynuowały przejętą wielokrotnie już w okresie okupacji odpowiedzialność za zabezpieczenie potrzeb materialnych rodziny, ponieważ uzyskiwane przez nie zarobki gwarantowały możliwość zaspakajania potrzeb całej rodziny. Przymus ekonomiczny powodował, że nie podejmowały rozpoczętej przed wojną kariery edukacyjnej: Nawet nie wiem, czy te siedem klas skończyłam i zaczęłam szukać pracy, ja musiałam pracować, zaczęłam pracować na szwalni i miałam bardzo dobrze, bo byłam młodziutka, mieliśmy taka swoja taśmę młodzieżowa, bardzo dużo wyrabiałam, premie dostawałam, nagrody, bardzo dobrze zarabiałam $w$ tej szwalni (O/3). Przymus ekonomiczny zniweczył aspiracje edukacyjne tych, które chciały się uczyć: Miałam zamiar uczyć się, marzyłam o tym, by zostać pielegniarka, ale mnie zycie zmusiło żeby pracować. Musiałam iść do pracy, trzeba było iść pomagać ojcu, pracować, żeby resztę rodziny utrzymać. Kto starszy, to poszedl do pracy i pracowat, a później to już się nie chciało [pójść do szkoły], jak człowiek doróst do dwudziestego roku życia, potem wyszłam za maż to już było inne życie, już się nie chciato szkoty $(\mathrm{D} / 3)$.

Po zakończeniu II wojny światowej narratorki starszego pokolenia bez problemu znalazły zatrudnienie ${ }^{5}$. Niezależnie od faktu, że bezproblemowe wejście na rynek pracy w dużym stopniu wynikało z przesłanek ideologicznych (założenia polityki zatrudnienia państwa, która w pierwszych latach powojennych wyraźnie, poprzez akcje propagandowe i rozwój ustawodawstwa socjalnego, zmierzała w kierunku mobilizacji kobiet jako dodatkowej siły roboczej) (Titk ow 1995)

${ }^{5}$ Po 1950 r. kobiety w Polsce stanowiły od 45 do 48\% zawodowo czynnej ludności, przed 1970 pracowało 63\% kobiet w wieku powyżej 15 lat, w $1985-78 \%$, w $1992-66 \%$ (W e j n e r t 2001). 
oraz powojennej rozbudowy potencjału Łodzi jako miasta przemysłu włókienniczego ${ }^{6}$ - to niezaprzeczalnie w przypadku narratorek starszej generacji kobiet praca w socjalistycznym zakładzie pracy otworzyła im wykorzystaną szansę wyjścia ze skrajnej biedy, doświadczanej w okresie dzieciństwa, awansu z biedoty do grona szanowanych pracownic fabryk, wyposażała w poczucie niezależności, wartości i godności. Narratorki starszego pokolenia rozpoczęły swoją karierę zawodową jako nastoletnie dziewczyny i kontynuowały ją nieprzerwanie przez ponad 35 lat (niektóre nawet ponad 40 lat) w zakładach przemysłu włókienniczego, pracując jako szwaczki, prasowaczki, prządki w systemie dwu- lub trzyzmianowym: ja tylko praca i praca i praca $i$ do pracy, a w szwalni się pracowało jeszcze na dwie zmiany, od piatej rano, do 1-szej. Potem od 2-giej czy wpót do drugiej do wpót do 10, potem w uniwersytecie robilam i tak jakoś tak jakoś wypracowałam swoje 50 lat łacznie, też miałam takie dorywcze prace i tak się starałam tak sobie jakoś radziłam, a teraz już nie moge, jak już zapadłam na ten kręgostup...i teraz żeby tylko zdrowie mi dopisało, ja już nie muszę pracować, bo przecież wypracowałam swoje (ZB/3). Niemal wszystkie przez całe swoje życie zawodowe związane były z jednym miejscem zatrudnienia: $w$ jednym zakładzie pracy całe życie pracowałam, na przędzalni, na trzy zmiany, od poczatku do końca przez 35 lat (B/1). Jeśli decydowały się na zmianę miejsca pracy, to najczęściej z uwagi na niski poziom uzyskiwanych zarobków ${ }^{7}$ i konieczność godzenia ról rodzinnych z pracą zawodową (przede wszystkim samotne matki): miałam daleko do pracy, musiałam wstać bardzo wcześnie o czwartej, po czwartej pare minut już miałam tramwaj, tutaj przyszłam blizej (D/1); zwolniłam się ze szwalni bo myśmy bardzo mało zarabiali, bardzo niskie płace były, mnie nie było $w$ domu przez dziesięć godzin z dojazdem (ZB/3). Dzięki ciężkiej, wieloletniej pracy zawodowej kobiety starszego pokolenia zdołały wypracować, co prawda niskie, ale gwarantujące im w okresie starości stałe dochody w postaci emerytury. Większość z nich skończyła swoją aktywność zawodową w drugiej połowie lat 80 ., tylko nieliczne ze względu na zły stan zdrowia przez kilka lat korzystały z renty chorobowej. Nie wszystkie jednak w chwili nabycia uprawnień emerytalnych zdecydowały się na przejście na emeryturę. Niektóre, wstrzymując świadczenia, kontynuowały przez kolejne lata aktywność zawodową w pełnym lub niepełnym wymiarze czasu pracy, rezygnując z niej dopiero wtedy, gdy stan zdrowia w znaczący sposób im to

${ }^{6}$ Po II wojnie światowej Łódź pozostała miastem, którego rozwój gospodarczy do roku 1989 był pochodną inwestycji realizowanych w obszarze przemysłu włókienniczego. Nieprzerwanie do połowy lat 70. XX w. miasto zwiększało potencjał przemysłu włókienniczego, dopiero pod koniec tego dziesięciolecia w Łodzi zaznaczył się deficyt siły roboczej, spowodowany przez spadek migracji, wzrost liczby kobiet korzystających z urlopów wychowawczych i wcześniejszych świadczeń emerytalnych. W latach 80. łódzki przemysł włókienniczy wszedł w fazę recesji, będącej konsekwencją zahamowania rozwoju inwestycji przemysłowych (M a r c z y ń s k a - W i t c z a k 1996: 55).

${ }^{7}$ Poziom płac $\mathrm{w}$ przemyśle tekstylnym był relatywnie niższy w porównaniu do innych gałęzi przemysłu. 
uniemożliwił: było mi bardzo ciężko to jeszcze sobie rentę zatrzymałam i jak już miałam 61 lat to jeszcze zostałam na pół etatu, bo mnie tam bardzo lubiano, ja tam robiłam wszystko $i$ na portierni byłam i byłam sprzataczka, taka byłam do wszystkiego $(\mathrm{ZB} / 3)$.

Podobnie jak matki, karierę zawodową w zakładach włókienniczych rozpoczęły narratorki średniego pokolenia - jako prządki, tkaczki, snowaczki, szwaczki, brakarki - na przełomie lat 70. i 80., kontynuując pracę do momentu jej utraty na początku lat 90. Nie miały problemów z podjęciem zatrudnienia. Niektóre, będąc niepełnoletnie, czyniły to poprzez Ochotniczy Hufiec Pracy. Legitymują się bardzo zróżnicowanym ogólnym stażem pracy zawodowej, od 7 do prawie 25 lat. Duże zróżnicowanie stażu pracy średniej generacji jest rezultatem przerw w zatrudnieniu, wynikających z obowiązków macierzyńskich, niekiedy samowolnych zwolnień. W przeciwieństwie do swoich matek, niektóre często zmieniały miejsce zatrudnienia: Jak skończyłam 18 lat, to się poszło do pracy. Tu się pracowało, trochę tam się pracowało, trochę zakładów przeszłam. Na poczatku robiłam trochę $w$ hali sportowej $w$ kuchni. Potem robiłam w laboratorium, na Milionowej takie bawetniane jest. Potem robiłam w Pierwszych Zakładach, no i tam $w$ bawetnianych laboratoriach to było bardzo ciężko, bo tam trzeba było dźwigać bele, trzeba było samemu tak tarmosić, trudno było poprosić kogoś bo każdy swoja robote miał, żeby tamci nie czekali mieli postój, ciężko było. Człowiek musiał się zwolnić, bo nie dawat se rady samemu $(\mathrm{ZH} / 1)$.

\section{Ustabilizowanie sytuacji materialnej rodzin - uzyskanie względnej niezależności materialnej i samodzielności życiowej starszego pokolenia kobiet}

Praca zawodowa kobiet starszej generacji - w oparciu o stabilne zatrudnienie - umożliwiała im osiagnięcie stabilizacji sytuacji materialnej w okresie dorosłości na poziomie gwarantującym względne poczucie bezpieczeństwa materialnego w rodzinach prokreacji. Ponieważ najczęściej rodziny pochodzenia w niewielkim stopniu były w stanie zabezpieczyć materialnie podjęcie przez kobiety ról małżeńskich, odczuwalna poprawa materialnych warunków życia poprzedzona była kilkuletnim okresem wytężonej pracy obojga małżonków ${ }^{8}$ : Wszystkiego dorabialiśmy się z mężem sami od widelca, od talerza, od spania (T/3); Pieniadze zawsze $w$ domu byty, rodzice odkładali, kupili telewizor jako pierwsi w kamienicy, kupili dziatke, planowali budowę domu (R/3); Jak przyszedt urlop, to jak byty dzieci, to co roku wyjeżḋaliśmy na Mazury, nad

${ }^{8}$ Należy wyraźnie podkreślić, że o uzyskaniu w rodzinach kobiet równowagi materialnej zadecydował także w dużym stopniu brak traumatycznych doświadczeń, dotyczących sfery życia rodzinnego (głównie problemu alkoholowego męża). 
morze (D/3). Znaczący wpływ na poprawę sytuacji materialnej miała bardzo często wykorzystywana przez kobiety możliwość podejmowania dodatkowej pracy w miejscu stałego zatrudnienia: Jak było mało pieniędzy, to sie poszło na ,nadróbkę” do zakładu. Dostałam w środę to 300 czy tam 280 złotych, to ja już miałam na jedzenie do końca tygodnia. (D/3). Kobiety dorabiały także poza miejscem stałego zatrudnienia: Jak miałam za mało za swoja prace na cały etat, to ja brałam pół etatu jeszcze, sprzqtałam klasy, i w ten sposób sobie dorobiłam $(\mathrm{O} / 3)$; dawałam sobie radę, pracowatam na szwalni, i jeszcze chodzitam do takich bogatszych ludzi sprzatać po pracy na szwalni, chodziłam na godzinke, dwie, zakupy zrobiłam, trzeba byto odkurzyć, sprzatnać, czasem przygotowatam obiad, nie była to żadna ciężka praca dla mnie, dwa lata tam pracowatam i tak sobie jakoś radziłam (ZB/3). Na stabilizację sytuacji materialnej w znaczący sposób wpływały transfery socjalne, oferowane przez socjalistyczny zakład pracy. W sytuacjach kryzysowych poczucie bezpieczeństwa gwarantowała możliwość zadłużania się w ramach oferowanych przez zakład pracy świadczeń socjalnych: $W$ każdej pracy pożyczki brałam, chwilówki, jednej nie spłaciłam, to już drugq wzięłam, wszędzie jakoś tak każdy mi szedt na rękę (ZB/3). Realizację ról rodzinnych i zawodowych ułatwiały gwarantowane przez zakład pracy uprawnienia pracownicze, tj. urlopy macierzyńskie i urlopy wychowawcze, dni wolne na opiekę nad dziećmi, możliwość korzystania ze zwolnień lekarskich, przejęcie części funkcji opiekuńczych przez instytucje (żłobki czy przedszkola). Większość narratorek starszej generacji po urodzeniu dzieci wykorzystywała jedynie urlop macierzyński, po czym wracała do pracy, łącząc aktywność zawodową z opieką nad dziećmi, która bardzo często realizowana była przy znaczącym współudziale dziadków. Na urlop wychowawczy (nie zawsze w pełnym wymiarze czasu) zdecydowały się tylko nieliczne z kobiet, tylko wtedy, gdy nie mogły w opiece nad dzieci liczyć na pomoc dziadków oraz, gdy zarobki osiagane $\mathrm{z}$ tytułu zatrudnienia i dochody uzyskiwane przez męża z pracy dodatkowej po godzinach wystarczały na zaspokojenie potrzeb. Wracały do pracy w momencie, gdy najmłodsze z dzieci osiagało wiek przedszkolny. Zdecydowanie częściej niż matki, z trzyletnich urlopów wychowawczych, wprowadzonych w latach 70., korzystały kobiety należące do średniej generacji, które w latach 80., po wykorzystaniu urlopu wychowawczego, często wydłużonego przez urodzenie drugiego dziecka, miały szansę powrotu do zakładu pracy na to samo stanowisko9.

${ }^{9}$ Urlop przysługiwał kobietom w okresie do czwartego roku życia dziecka i nie dłużej niż sześć lat, gdy w trakcie urlopu urodziła drugie dziecko. Zakład pracy był zobowiązany udzielić takiego urlopu na życzenie kobiety w terminie dla niej dogodnym i zagwarantować wszystkie uprawnienia pracownicze (ubezpieczenie, korzystanie z funduszu zakładowego itd.). Jeśli dochody w rodzinie były niskie, przysługiwał zasiłek wychowawczy. Na przełomie lat 70 . i 80 . kobiety z rodzin robotniczych decydowały się na urlop wychowawczy, gdy brak ich zarobków nie powodował znaczącego obniżenia poziomu życia rodziny (P o t o c z n a, Wa r z y w o d a - K r u s z y ń s k a 2009). 


\section{Pozostawanie poza rynkiem stałej pracy jako doświadczenie średniego i młodszego pokolenia kobiet}

Sytuację zawodową średniej generacji kobiet radykalnie zmieniła transformacja systemowa lat 90 . W wyniku procesu restrukturalizacji przemysłu włókienniczego, Łódź okazała się miastem szczególnie narażonym na strukturalne bezrobocie i pauperyzację mieszkańców. Już na początku transformacji, w latach 1990-1993, odnotowano w Łodzi znacznie większy niż przeciętnie w innych miastach przemysłowych spadek produkcji i zatrudnienia (Kwiatk owski 2007; Now a ko w sk a 1996; Rynek pracy $w$ Lodzi... 2003) oraz wzrost liczby świadczeniobiorców pomocy społecznej, wśród których dominowały kobiety (Warzywoda-Kruszyńska, Grotowska-Leder 1996). Zwolnienia grupowe i upadek kolejnych zakładów powodowały wzrost bezrobocia wśród kobiet ${ }^{10}$.

Podstawową cechą biografii zawodowych kobiet średniego pokolenia jest doświadczenie utraty stałej pracy zarobkowej i wejście w sytuację bezrobocia w pierwszych latach transformacji (1991-1993) bez żadnych szans na powrót w kolejnych latach do stałego, legalnego zatrudnienia ${ }^{11}$. Teraz szósty rok mija, jak już nie pracuje $(\mathrm{ZH} / 1)$. Dla wielu z nich moment ten zbiegł się z terminem powrotu do pracy po okresie pobytu na urlopie wychowawczym. Niestety, powrót ten oznaczał niemal natychmiastowe (lub w bardzo krótkim czasie) zwolnienie z pracy pod jakimkolwiek pretekstem. Niektóre straciły pracę w ramach zwolnień grupowych, inne zostały zwolnione w sposób, który pozbawił je odpraw przysługujących w ramach zwolnień grupowych: Ani jednej nagany nigdy nie miałam, dodatkowe prace bratam, a kierowniczka daje mi wymówienie, byłam po dtugiej chorobie. Zwalniali pojedynczo, bo inaczej, to należała mi się wyprawka, niestety nic nie dostałam, bo pojedynczo byliśmy zwalniani (ZP/1). Dla ich córek, młodszej generacji kobiet biorących udział w badaniu, okres lat 90 . oznaczał zakończenie procesu edukacji i podjęcie nieudanej próby wejścia na rynek pracy, niestety, bez odpowiednich kwalifikacji zawodowych, potwierdzonych ścieżką kariery edukacyjnej ${ }^{12}$. Już u progu kariery zawodowej doświadczyły wykluczenia ze sfery legalnej, stałej pracy zarobkowej ${ }^{13}$. Ich szanse na realizację kariery

\footnotetext{
${ }^{10}$ Wskaźnik bezrobocia kobiet w 2002 wynosił 52,4\%, w lutym $2003-49,3 \%$.

${ }^{11} \mathrm{~W}$ trakcie realizacji badania tylko jedna z kobiet średniej generacji pracowała leganie i jedna była zatrudniana ,na czarno”.

${ }^{12}$ Większości z nich udało się jedynie ukończyć szkołę podstawową, nielicznym zasadniczą szkołę zawodową, dwie ukończyły średnią szkołę ogólnokształcąca, a te, które nie radziły sobie w szkołach publicznych, kończyły szkoły specjalne lub szkoły w ramach OHP. Konsekwencją niskiego poziomu wykształcenia jest brak kwalifikacji zawodnych, który utrwala słabą pozycję na rynku pracy.

${ }^{13} \mathrm{~W}$ doświadczenie jedynie dwóch wpisuje się krótki epizod stałego zatrudnienia oraz krótsze lub dłuższe okresy pracy „na czarno”. Połowa młodych kobiet w chwili realizacji badania (1998) nigdy nie pracowała zarobkowo.
} 
zawodowej ograniczał brak dostatecznych kompetencji, pozwalających na funkcjonowanie w warunkach gospodarki rynkowej. Będąc poza rynkiem pracy, nie nabywały kompetencji, potrzebnych do wykonywania pracy zawodowej, nie były w stanie rozwijać posiadanych i zdobywać żadnych nowych umiejętności. Choć wszystkie w trakcie realizacji badania deklarowały chęć podjęcia pracy po wychowaniu dzieci, większość z nich nie potrafiła ocenić swoich szans i możliwości na rynku pracy, planując pójść do pracy „gdzieś”, zupełnie obojętnie gdzie, ważne jest, ,żeby tylko zarobić”. Większość z nich nie miała żadnych planów i nie podejmowała działań, zmierzających do kontynuowania nauki ${ }^{14}$. Dla tych, które pełniły role rodzicielskie, pozostawanie poza rynkiem pracy oznaczało brak możliwości skorzystania z uprawnień rodzicielskich (urlop macierzyński, wychowawczy) i socjalnych (zakładowy fundusz socjalny), a także innych form wsparcia, oferowanych przez zakłady pracy.

\section{Praca dorywcza i „na czarno” w doświadczeniu średniej i młodszej generacji kobiet}

Począwszy od lat 90., kariery zawodowe średniej i młodszej generacji kobiet kształtowały się pod presją warunków transformacyjnych. Średnie pokolenie kobiet weszło w okres transformacji z doświadczeniami ukształtowanymi w warunkach społeczeństwa przemysłowego, w tym z kapitałem edukacyjnym, który był wystarczający do podjęcia pracy w okresie wcześniejszym ${ }^{15}$. W nowej rzeczywistości stosowane wcześniej sposoby radzenia sobie z problemami życia codziennego stały się nieadekwatne i wymuszały wypracowanie nowych strategii adaptacyjnych. Ponieważ niepowodzeniem kończyło się poszukiwanie legalnej pracy zarobkowej ${ }^{16}$, a w połowie lat 90 . problemem stało się nie tylko znalezienie stałej pracy zarobkowej, lecz także pracy na podstawie jakiejkolwiek umowy, pierwsze lata po utracie zatrudnienia wpisały w doświadczenia kobiet krótsze lub dłuższe sekwencje bezrobocia i pracy „na czarno”. Narratorki, które potrafiły szyć na maszynie, podjęly pracę chałupnicza, oferowaną przez prywatne zakłady szwalnicze, nierejestrowana, wyczerpująca, przynoszącą bardzo nieregularne i niskie dochody: Pracuję na akord. Ile uszyje, za tyle mam zapłacone [...] można powiedzieć, że te dochody to byty takie różne, bo jak trzeba, to się szyje i dzień i noc i na nastęny dzień tak, że w sumie praca $w$ domu to jest praca non stop, no jeżeli jest martwy sezon, gdzie trudno jest zarobić, to z ledwościa się wychodzi na tyle, żeby opłacić świadczenia, a nie mówiac jeszcze o życiu, żeby przeżyć z córkq za dwieście złotych z groszami, to naprawdę

${ }^{14}$ Tylko jedna z kobiet zamierza po odchowaniu dzieci pójść do liceum wieczorowego.

${ }^{15}$ Większość z nich ma wykształcenie podstawowe, zasadnicze zawodowe, a tylko nieliczne - średnie.

${ }^{16}$ Nieliczne znalazły pracę sprzątaczki czy woźnej w szkole na umowę zlecenie lub na czas określony. 
jest nam trudno, teraz po prostu człowiek liczy każdy grosz, chwytam się wszystkich prac dorywczych jakie sq i żyję (X/1); Pracowatam w piekarni 2 tygodnie na noce, nie chciat [pracodawca] mnie zarejestrować, wypłacił 70 zł, poszłam do opieki pokazałam, a oni powiedzieli, że nie maja wptywu na biznesmenów, to była ciężka praca i zrezygnowałam, bo ani nie ubezpieczyt mnie tylko na dziko (ZP/1). Z biegiem lat możliwości zatrudnienia „na czarno” stawały się coraz bardziej ograniczone, z uwagi na upadek lub likwidację prywatnych zakładów wydłużały się okresy braku pracy zarobkowej, w konsekwencji okresy pracy „na czarno” przeplatały się z okresami pobierania zasiłku z pomocy społecznej. Niektóre, żeby zdobyć umiejętności, które dawałyby szansę znalezienia pracy, uczestniczyły w różnego rodzaju kursach zawodowych, organizowanych przez Urząd Pracy. Niestety, ukończenie kursów nie rozwiązuje problemu braku zatrudnienia: Starałam się o prace, ale nie ma nigdzie, latam i szukam tej roboty, po pierwszym kursie opiekunki społecznej nie ma pracy, miałam szkolenie w pośredniaku, więc poszłam na drugi kurs, też nie ma pracy i nie będzie, jak nam powiedziano. A dlaczego, bo przyjmuja rencistów i emerytów do pracy $i$ nie płaca za nich ubezpieczenie i nie martwi się rzad z czego my będziemy zyć. No bo przecież ja ten kurs kończę po to, żeby naprawdę mieć na ten chleb zarobić, ale niestety gdzie tylko obeszłam, nigdzie nie ma przyjęć, nie wiem co robić dalej, widzę że nie mam już żadnej nadziei. Dlatego robiłam te kursy, bo sadziłam, $\dot{z}$ e po tych kursach jako nawet salowa, nie ma żadnej nadziei, żebym ja jakakolwiek dostała i po takim szkoleniu (ZP/1); Kilkakrotnie zapisałam się na kursy w wydziale zatrudnienia, ale nigdy nie doszło do petnej obsady na kurs i nigdy na ten kurs nie poszłam, bo albo było za mało kandydatów, albo mnie nie przyjęto, bo mam dzieci, bo kursy były organizowane $w$ porze nocnej (ZL/1). Także w przypadku młodszej generacji kobiet jedyną szansą podjęcia zatrudnienia jest praca „na czarno”: Byłam wykorzystywana przez szefa, on mnie zarejestrowat jako uczennice a pracowałam na całym etacie, normalnie bytam na stanowisku przez 8 godzin i do tego wymyślat sobie Bóg wie jakie manka, że 2-ch milionów nie ma czy tego nie ma i co ja dostawałam, bardzo marne grosze dostawałam miesięcznie, tyle ile wytrzymałam, a już później zrezygnowałam, no bo za takie grosze pracować (Z/3); praca na szwalni to była taka praca, na przykład jeden miesiac mogłam pracować od rana do wieczora, a byt taki okres przez dwa trzy tygodnie, że w ogóle nie było pracy, trzeba było wziać urlop, pracowałam jako pomoc szwaczki, byłam takie popychadto, widza młoda dziewczyne, nieumalowana, włosy nie podkręcone, zobacza taka dziewczyne to można sobie robić co się podoba, ale jakoś tam poszłam, przepracowałam i kupiłam dziecku buty (ZB/3). Jedna z młodych kobiet, zmuszona do podjęcia pracy przed urodzeniem dziecka, nie przyznawała się do tego faktu: jak tylko zaszłam w ciaże, musiałam ukrywać, że jestem w ciaży, bo tak by mnie nie przyjęli do pracy, ja musiałam podjać prace żeby kupić to, co było potrzebne dla dziecka, musiałam pokupować rzeczy, które byty potrzebne, tym bardziej że chtopak jeszcze siedziat, dlatego do trzeciego miesiaca ukrywatam ciażę (E/3). Starając się o ponowne wejście na rynek pracy, kobiety średniej generacji doświadczają wielu przejawów 
dyskryminacji. W nowych warunkach gospodarczych okazały się mało atrakcyjne na rynku pracy ze względu na wiek, stan zdrowia, a także posiadanie dzieci: Chodzę i szukam pracy i naprawde nie ma, bo gdzie czlowiek idzie $i$ spyta o prace to oni: ile pani ma lat, ja na to 42, no to styszę dziękuje, nie ma, chętnie bym chciała gdzieś iść do pracy, ale nie chca mi dać pracy, bo mam za dużo lat (ZB/1). Znaczącym ograniczeniem w uzyskaniu pracy są także poważne problemy ze zdrowiem: $J a$ mam taki stan zdrowia, że mnie nie chcq wszędzie przyją́ do pracy, bo ja mam anemie duża, moje wyniki sq stabe $i w$ wielu zaktadach mi wtaśnie prace odmawiano (F/1). Niektóre uzyskały rentę chorobowa, ale w związku ze zmianami przepisów utracily to świadczenie: Byłam na rencie, ale była na dwa lata, ale zabrali mi, bo stwierdzili, że jestem zdrowa. A mam epilepsję i z ta chorobq trudno iść do zaktadu pracować, bo żaden zakład nie przyjmie (ZP/1). Znaczącą barierą wejścia na rynek pracy, zarówno dla średniej generacji, jak i dla młodych kobiet, okazało się obciążenie obowiązkami rodzicielskimi: po prostu nikt mnie nie chce przyjąć, bo mam mate dziecko, jak się dowiadywałam to po prostu nie chcq (Z/3); Gdy dziecko skończyto pót roku to mnie do pracy wystali [PUP], no to pojechałam ale mnie nie chcieli, bo za małe dziecko jeszcze byto, pojechatam do nich z powrotem [PUP], dałam im ten papierek, że dziecko jest jeszcze za małe, że nie chcq mnie przyjać, to dali mi druga prace, do drugiej pojechałam, to chcieli mnie zatrudnić, tylko że to byto za daleko, a nie miat kto mi dzieckiem się zajać (E/3). W konsekwencji tylko nielicznym po urodzeniu dziecka udawało się podjąć pracę dorywczą, najczęściej jednak tylko na krótki okres, ponieważ z uwagi na brak wsparcia w wypełnianiu obowiązków rodzicielskich, niekiedy z uwagi na zły stan zdrowia dzieci musiały z niej zrezygnować: co $z$ dwójkq dzieci zrobić, nie mogę ich samych zostawić (M/3). W konsekwencji, w przypadku obu generacji kobiet, brak możliwości podjęcia i udokumentowania legalnej pracy zawodowej pozbawia je prawa do zasiłku dla bezrobotnych i nie daje gwarancji bezpieczeństwa socjalnego na starość, ponieważ uniemożliwia wypracowanie stażu pracy, uprawniającego do uzyskania świadczeń emerytalnych.

\section{Wejście w degradującą przestrzeń społeczną enklaw biedy średniej i młodszej generacji kobiet}

Doświadczeniu utraty stałej, legalnej pracy zarobkowej, a z biegiem lat braku możliwości podejmowania pracy dorywczej towarzyszy degradacja materialnych warunków życia oraz ograniczenie możliwości i szans życiowych ${ }^{17}$. Kobiety średniej generacji wpadły w spiralę zadłużenia. Mają poważne zaległości w regulowaniu bieżących świadczeń: Zaległa jestem ze świattem, zaległa jestem

${ }^{17} \mathrm{~W}$ momencie realizacji badań kobiety nie miały uprawnień ani do zasiłku dla bezrobotnych, ani do świadczeń przedemerytalnych, utrzymywały się z zasiłków z pomocy społecznej i wsparcia swoich matek. 
$z$ komornym, mam trochę dlugów i chciałabym naprawdę iść do pracy, żeby wyjść $z$ tego. Mama mi nie pomoże, bo też sama nie ma, ojca nie mam, rodziny żadnej bliskiej nie mam, tylko mam mamę (ZB/1); Nie stać mnie na to ogrzewanie, więc jest wytaczone. Przyszli elektrycy, odłaczyli to ogrzewanie, bo nie starczyto na ogrzewanie [...] mam straszne problemy finansowe (N/1). W konsekwencji jednym z najbardziej obciążających doświadczeń staje się utrata szansy utrzymania lub poprawy warunków mieszkaniowych ${ }^{18}$. Kobiety, które dzięki staraniom rodziców zdążyły wprowadzić się do nowych, własnych mieszkań, nie są w stanie ich utrzymać. Kilka z nich wyeksmitowano, inne, w obawie przed utratą dachu nad głową (na skutek ograniczenia możliwości regulowania opłat za lokum) zamieniały mieszkania „za odstępne” na mniejsze, w starej kamienicy, w enklawie biedy: Nie miałam z czego opłacać, więc zaczęłam szukać i zamieniałam się na to mniejsze na dwa pokoje z kuchniq, żeby córka miała swój i my z mężem sobie. Teraz przyjdzie za gaz nie wiem z czego zapłace, bo wodę mam nie płacona już od czerwca, bo to można raz na pót roku płacić, można co miesiqc, ale nie wiem z czego zaptace, światto staram się ptacić, bo przyjdq odtacza, telewizor się zepsuł nie mamy telewizora, no taka prawda. Bida straszna, pralka się zepsuła, nie mam z czego zreperować, wszystko w ręku piorę, no i takie życie jest, wegetacja po 25 latach pracy $(\mathrm{ZH} / 1)^{19}$.

Wyraźnie zarysowaną cechą analizowanych biografii narratorek średniego pokolenia jest traumatyzujące poczucie marginalizacji, wykluczenia, frustracji z powodu braku pracy. Rzeczywistość neoliberalnego rynku pracy pozbawiła je możliwości uzyskiwania stałych dochodów, niezbędnych do zaspokajania codziennych potrzeb życiowych, poczucia bezpieczeństwa, obciążając także doświadczeniem ,specyficznej psychologicznej dyslokacji”, wynikającym z silnego poczucia nieefektywności starań na rzecz powrotu na rynek, frustracji, bezradności, beznadziejności i pesymizmu (por. Wal c zak 2000): żeby człowiek chociaż poszedt na jakieś sprzqtanie, czy na coś, ale nie ma, nie potrzebuja, $w$ pośrednia$k u$ nic nie oferuja, chociaż jestem zarejestrowana, chodze, odhaczam się (L/1). Nieefektywność podejmowanych działań powoduje, że biegiem lat ograniczają próby poszukiwania pracy, zwiększa się ich podatność na zaburzenia depresyjne, lęk i obawy o przyszłość: Człowiekowi się nic nie chce, ja jestem taka załamana, ze mi się nic nie chce kompletnie, ja potrafię catymi tygodniami z domu nie wychodzić, tylko teraz stucham radia i czytam ogłoszenia w prasie. [...] Chodzę do takich prywaciarzy, pytam o jakaś pracę chałupnicza, ogłoszenie dawałam przez

\footnotetext{
${ }^{18}$ Niektóre z kobiet otrzymały mieszkania spółdzielcze w blokach, co umożliwił zgromadzony przez rodziców wkład członkowski na książeczkach mieszkaniowych.

${ }^{19}$ Jak wynika z badań zrealizowanych w 2010, kolejne lata bez pracy wyczerpały możliwości badanych w kwestii radzenia sobie z regulowaniem należności za czynsz. W wielu przypadkach mieszkanie w substandardowej kamienicy stało się także pułapką, ponieważ w wyniku procesu reprywatyzacji łódzkich kamienic dalsza zamiana lokali na jeszcze tańsze okazała się niemożliwa z powodu braku chętnych na zamianę (War zy w o da - K r u s zy ń s ka, J a n k o w s ki 2013).
} 
telefon do radia, że poszukuję pracy jakiejś chałupniczej, ale nic takiego nie ma. Ja już nie widzę $w$ ogóle żadnej przyszłości, żadnej nadziei, tak żyję z dnia na dzień [...]. Mam 51 lat, a czuje sięjakbym miała 70 (B/1); Córka bardzo dlugo nie mogła znaleźć pracy, źle wyglada, bardzo źle, nerwowa taka jest, jak była redukcja w zaktadach, bo skończyła szkote pończosznicza, no to zwolniono ja i miata kłopoty ze znalezieniem pracy, $i$ w tej chwili to już ma w 54 lata, to już nie może dostać pracy, dlatego poszła tutaj do centrum kultury i tutaj po prostu sprzata i ona sobie nie może darować tego, że ona musi sprzatać, ma dwoje dzieci, w taka nerwice wpadta, że ja jej nie poznaję, ona krzyczy teraz, jakaś taka chaotyczna się zrobiła, ja nie wiem co to będzie dalej, jest chora, ja widzę, że jest nerwowo chora (ZG/3). Badania zrealizowane 10 lat później (2008) pokazały, że z uwagi na znaczne pogorszenie stanu zdrowia kobiety średniej generacji całkowicie zostały wykluczone z rynku pracy. Wiele z nich wpadło w pułapkę kredytową parabanków lub komercyjnych firm kredytowych, których naliczane prowizje i odsetki pochłaniają większość skromnych dochodów (Warzywoda-Kruszyńska, J a nk ow sk i 2013). W przypadku młodszej generacji oferowane przez sprywatyzowany łódzki przemysł lekki miejsca pracy ograniczają się do prac pomocniczych w szwalniach, pracowniach krawieckich, małych firmach odzieżowych, niekiedy pracy sprzątaczki, dozorczyni, nadal najczęściej są to prace dorywcze, „na czarno", przynoszące bardzo niskie zarobki, które pozwalają zaspokoić zaledwie najpilniejsze potrzeby, a nie wypracować jakąkolwiek stabilizację finansową (Warzywoda-Kruszyńska, Jankowski 2013). Brak stałego zatrudnienia kobiet młodszej generacji skutkuje brakiem samodzielności ekonomicznej i mieszkaniowej. W ich doświadczenie wpisuje się już w trwały sposób uzależnienie od świadczeń instytucji pomocy społecznej. Brak możliwości uzyskania pracy dającej poczucie stabilizacji staje się trwałym elementem doświadczenia biograficznego kolejnej, czwartej, najmłodszej generacji kobiet, urodzonych już po 1989. Jak konkludują autorzy badań: ,jest to pokolenie najbardziej zdezorientowane i zagubione - absolutnie nie przygotowane do życia we współczesnych realiach ekonomicznych i zupełnie pozbawione korzeni" (Jankowski, Warzywoda-Kruszyńska 2010: 41).

\section{Zakończenie}

W doświadczeniu biograficznym każdej z trzech generacji narratorek dostęp do pracy warunkowany przez procesy społeczno-ekonomiczne, wyznaczające odmienne warunki i możliwości realizacji aspiracji zawodowych, ma konstytutywne znaczenie, zarówno dla strukturalizacji przebiegu życia, jak i subiektywnego doświadczania biedy. Proces intensywnej industrializacji i nacjonalizacji przemysłu, gwarantując kobietom starszej generacji szeroki dostęp do stałej, legalnej pracy zawodowej, umożliwił im wyjście z biedy doświadczanej w okresie dzieciństwa, 
a także wypracowanie zabezpieczenia socjalnego na starość. Przebieg ich wieloletniej kariery zawodowej zamknął się w okresie socjalizmu, oferującym poczucie pewności i stabilności zatrudnienia. Tych możliwości i szans zostały pozbawione generacje średnia i młodsza. Doświadczając utraty pracy po 1989 r., średnie pokolenie narratorek boleśnie odczuwa ,ześlizgnięcie się w trwałą biedę”. Dla kobiet młodszej generacji, z uwagi na brak wykształcenia i kwalifikacji zawodowych, brak stałej pracy zawodowej stanowi podstawowe doświadczenie biograficzne. Z dużym prawdopodobieństwem skazane na brak pracy będzie pokolenie najmłodszych mieszkanek enklaw biedy. ,W trakcie dziesięciolecia w łódzkich enklawach biedy wykształciła się bieda chroniczna, doświadczana przez całe życie lub jego większość. Bieda nie jest już epizodem w cyklu życia, ale staje się «kapitałem» przekazywanym dzieciom" (War zy w o da-Kruszyńs ka, Jank ow ski 2013: 51).

\section{Bibliografia}

B e c k U. (2002), Społeczeństwo ryzyka. W drodze do innej rzeczywistości, Wydawnictwo Naukowe Scholar, Warszawa.

G olc zyńska-Grondas A. (2004), Mężczyźni z enklaw biedy. Rekonstrukcja petnionych ról społecznych, Wydawnictwo ABSOLWENT, Łódź.

J a n k o w s k i B., Wa r z y w o d a - K r u s z y ń s k a W. (2010), Mieszkańcy tódzkich enklaw biedy 10 lat później, Wydawnictwo Biblioteka, Łódź.

K w i a t k o w s k i E. (2007), Zróżnicowanie regionalne bezrobocia i jego uwarunkowania w Polsce w latach 1991-2005, [w:] W. N o w a k - S a p o t a, R. K n a p a (red.), Dylematy bezrobocia w ujęciu regionalnym, „Zeszyty Naukowe Szkoły Wyższej im. Pawła Włodkowica w Płocku", nr 30, s. 9-27.

M a r c z y ń s k a - W i t c z a k E. (1996), Zmiany struktury gospodarczej Łodzi, [w:] W. M i c h a ls k i (red.), Transformacja społeczno-gospodarcza Łodzi na tle regionu, Polskie Towarzystwo Geograficzne, Łódź, s. 48-57.

Now a kow ska B. (1996), Rynek pracy $w$ Łodzi, [w:] W. Michalski (red.), Transformacja społeczno-gospodarcza Łodzi na tle regionu, Polskie Towarzystwo Geograficzne, Łódź, s. $9-14$.

P ole s zc zuk J. (1991), Praca w systemie gospodarki planowej, [w:] M. M a rody (red.), Co nam zostało z tych lat... Społeczeństwo polskie u progu zmiany systemowej, Wydawnictwo Aneks, Londyn.

P ot o c zna M., Warzyw oda-Kruszyńska W. (2009), Kobiety z łódzkich enklaw biedy. Bieda w cyklu życia i międzypokoleniowym przekazie, Wydawnictwo Uniwersytetu Łódzkiego, Łódź.

Rynek pracy w Łodzi. Diagnoza (2003), Urząd Miasta Łodzi, Wydział Strategii i Analiz, Łódź.

T i tk o w A. (1995), Kobiety pod presja? Proces ksztaltowania się tożsamości, [w:] A. K w a k, H. D o m ań s k i (red.), Co to znaczy być kobieta w Polsce, IFiS PAN, Warszawa, s. 9-39.

W a 1 c z a k R. (2000), Obraz siebie u kobiet dlugotrwale bezrobotnych, Katolicki Uniwersytet Lubelski, Lublin.

Warzywoda-Kruszyńska W., Grotowska-Leder J. (1996), Wielkomiejska bieda w okresie transformacji, Wydawnictwo OMEGA-PRAKSIS, Pabianice.

Warzy w od a-Kr u s zyńs ka W., Jank ow ski B. (2013), Ciagłość i zmiana w łódzkich enklawach biedy, Wydawnictwo Uniwersytetu Łódzkiego, Łódź. 
We j n e r t B. (2001), Wpływ przeobrażeń politycznych na zmiany ról społecznych kobiet. Studium porównawcze okresu socjalizmu i poczqtków demokracji, [w:] A. W a c h o w i a (red.), Jak żyć. Wybrane problemy jakości życia, Wydawnictwo Fundacji „Humaniora”, Poznań.

Malgorzata Potoczna

\section{WORK IN BIOGRAPHICAL EXPERIENCE OF THREE GENERATIONS OF WOMEN FROM ENCLAVES OF POVERTY IN LÓDŹ}

Summary. Łódź is renowned as a city of working women. For over two hundred years, the development of the city, the lives and professional experiences of its residents, especially its women, have been intertwined with textile and clothing industry which has offered employment primarily to them. The paper draws attention to the role of gainful employment in the biographical experience of three generations of Łódź women in terms of the shaping of their fortunes. It focuses on the major role played by changes in the Łódź labour market in terms of the escape from or descent into poverty by female residents of industrial Łódź. These changes are determined by historical events (World War II) but above all by socio-economic processes i.e. the economic downturn in the interwar years, post-war systemic transformation and the systemic transformation of the $90 \mathrm{~s}$. In the case of the older generation of female residents of Łódź, the post-war systemic transformation, mainly the process of intensive industrialisation and nationalisation of industry, while guaranteeing a broad access to professional work, offered an opportunity to escape the poverty they experienced in the interwar period in their families of origin; an opportunity which many of them grasped. As regards the generation of their daughters who entered adulthood in the late 70 s and early 80 s, they undertook occupational activity without major problems, as their mothers did. Work offered them the opportunity to maintain a relatively stable material situation in the next generation. The process of restructuring of the Łódź textile industry which started in the 90s impacted significantly on the fates of women of the middle generation and the younger generation that followed. As a consequence of these changes, the middle generation of women lost the opportunity to maintain stable employment. Younger women find it impossible to gain employment at all and are thereby rendered redundant in the labour market.

Keywords: work, women's poverty, systemic transformation, social exclusion. 